\title{
Determinants of Accountability in the Bureaucracy: The Case of Nepal
}

\author{
Ramesh C. Paudel1,2*, Anil Kumar Gupta ${ }^{3}$ \\ ${ }^{1}$ Central Department of Economics Tribhuvan University, Kirtipur, Kathmandu, Nepal \\ ${ }^{2}$ Crawford School of Public Policy and Governance, The Australian National University, Canberra, Australia \\ ${ }^{3}$ Training and Research Officer, Nepal Administrative Staff College, Jawalakhel, Nepal \\ Email: ^Ramesh.paudel@alumni.anu.edu.au
}

How to cite this paper: Paudel, R.C. and Gupta, A.K. (2019) Determinants of Accountability in the Bureaucracy: The Case of Nepal. Modern Economy, 10, 2085-2109. https://doi.org/10.4236/me.2019.109131

Received: July 31, 2019

Accepted: September 20, 2019

Published: September 23, 2019

Copyright (c) 2019 by author(s) and Scientific Research Publishing Inc. This work is licensed under the Creative Commons Attribution International License (CC BY 4.0).

http://creativecommons.org/licenses/by/4.0/

\begin{abstract}
Accountability of the position holders is an instrument for ensuring quality governance within the bureaucratic structure throughout the world, and Nepal is not an exception. Time and again, the government of Nepal has practiced various plans, policies, and institutional mechanisms to make duty bearers accountable for their actions and performance. However, it is a general feeling that still these have not resulted as expected. Citizens often feel that bureaucrats are being irresponsive and unaccountable, and bureaucrats are openly criticized. In this background, we examine the determinants of accountability in Nepali Bureaucracy using the primary data collected from 213 bureaucrats form the central level organization, i.e., Ministry of Education employing widely accepted framework as proposed by Yamane [56]. The estimated results show that the bureaucrats seem to be accountable. Transparency, responsibility, and responsiveness also appear to be good; however, liability and controllability were not found to meet the expectations. This scenario reveals that there is a weak controllability mechanism. Similarly, there was a weak system for performance-based reward and punishment. It is interesting to note that accountability of bureaucrats differs by their demographic attributes.
\end{abstract}

\section{Keywords}

Accountability, Transparency, Bureaucracy

\section{Introduction}

Accountability has been extensively accepted as a base of public sector governance all over the world, and Nepal is not an exception. Accountability is an in-

Corresponding Author. Email: ramesh.paudel@alumni.anu.edu.au. 
dispensable issue of a bureaucratic structure for bureaucrats' conducts, performances, actions, and decisions. Bureaucrats are expected and assumed to be accountable for their actions and performance to the public and different organizations. For this reason, bureaucrats are under pressure to justify not only functioning processes and financial deeds, but also improving the performance of their services delivery and results [1]. The bureaucrats have an obligation and responsibility to act in accordance with the rules, regulations, procedures, and standards set by governments. This helps to accomplish their duties successfully and support higher levels of performance.

Making the bureaucrats accountable and maintaining a competent level of overall bureaucracy is vital for every government [2]. As such, the Government of Nepal has paid ample attention and invested time and resources. Further to elaborate, numerous reform commissions, constitutional bodies, state institutions, laws, policies, directives, and guidelines have been formed over the years. In spite of this, practice and exercise of accountability within Nepali bureaucracy are not reported as expected. It is said that the Nepali bureaucracy has increasingly become dysfunctional, fragmented, poorly organized, and incapable of performing at a level acceptable to the public [3]. They are blamed for being inefficient, ineffectiveness, buck-passing, delaying, having self-seeking behaviors, being unaccountable, corrupt, non-transparent, and irresponsible [4] [5]. Public perception is that no official work can be done without paying bribe [6]. Bureaucrats are unable to create a positive impression among citizens whom they serve [3].

As per Transparency International, Nepal has been placed $139^{\text {th }}$ (out of 176),

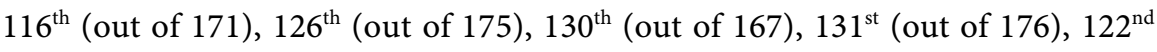
(out of 176) in 2012, 2013, 2014, 2015, 2016, and 2017 respectively in the corruption perception index. Just over one in three people distrust bureaucrats, rating them as not very honest (21.8\%) or not honest at all (12.8\%) [7]. This scenario reveals that Nepali bureaucracy is suffering from low level of accountability.

The failures in accountability are systemic, rather than attributable to individual actors. The task of making bureaucracy more productive, efficient, cost-effective, service-oriented, trustworthy, transparent, responsive, and initiative-taking has been a challenge [8]. These challenges can be addressed through effective practice and exercise of accountability because accountability plays a crucial role to ensure efficient, effective, competent, prompt, responsive, transparent, and trustworthy bureaucracy. Bearing such thing in the mind, we adopted five typologies of accountability namely transparency, liability, controllability, responsibility, and responsiveness to examine the determinants of accountability in Nepali bureaucracy. The main purpose of this paper is to examine the determinants of accountability in Nepali bureaucracy. To achieve this, we make a thorough analysis of accountability and relevant literature adding it in the Nepalese context. Then, we also focus on the following research questions: 1) What is the level of accountability? 2) To what extent do accountability differ based on demographics? These questions are answered using the primary data to 
suit the research context.

The results show that the bureaucrats seem to be accountable. Further, transparency, responsibility, and responsiveness also appear to be good; however, feelings towards the liability and the mechanism of controllability were not found to meet the expectations. This scenario reveals that there is a weak controllability mechanism that has played crucial role to expose the bureaucracy as unaccountable. This finding supports the findings of [9] that states the labor force have not contributed in the overall development of the country.

This paper is organized as follows. The following section discusses the relevant literature. We discuss about the research methodology and discuss the results in Section 3. The final section concludes.

\section{Literature Review}

\subsection{What Is Accountability?}

Accountability is the central pillar of good governance. It has been frequently used by citizens, politicians, policy makers, practitioners, bureaucrats, and academicians. However, accountability is defined and perceived in various ways in the literature. It has been described as a narrow or broad [10], abstract [11] ever expanding concept [12], murky [13], complex and dynamic [14], golden concept [15], evocative and evaluative [16], normative [17], amorphous [18], buzzword or magic concept [19], multifaceted and complex [20] [21], icon of good governance [22] [23] [24], icon, hurrah-word and a chameleon [25]. From all of these scholars' views, it is clear that the nature and meaning of accountability varies.

Accountability means the process by which public sector organizations and their officials manage the diverse expectations generated within and outside the organizations [26]. For example, according to Koppell [27], accountability is a combined form of transparency, liability, control, responsibility, and responsiveness. However, in the view of Akerman [28], accountability is a proactive process where public officials inform and justify their plans of action and behavior, and results are sanctioned accordingly. In the same vein of Ackerman, Sirker [29] defines accountability as an obligation and compulsion of the duty bearer to take account of their actions in both their conduct and performance.

Many scholars have defined accountability as a relationship. According to Mulgan [30], accountability is the relationship of social interaction and exchange involving complementary rights on the part of the account-holder and obligations on the part of the duty bearer. Bovens [17] presents the most widely accepted definition of accountability. According to him, accountability is the relationship between an actor and a forum. An actor has an obligation to explain and justify his/her conducts and the forum can pose questions and pass judgment, as a result of which, the actor may face consequences. Hence, it can be said that accountability is the relationship between two or more parties where one party is obliged to give an account or justification of his/her conducts to another, and receive consequences accordingly. 
Keeping these views in mind allowed us to perceive and realize accountability as an obligation of the office bearer to take responsibility, give answers, justification and explanations for their behavior, actions, conduct and performance. For us, accountability is the combination of transparency, liability, controllability, responsibility, and responsiveness, as suggested by Koppell [27]; and informing or reporting, discussing, debating or justifying, and facing appropriate consequences, as discussed by Bovens [17].

\subsection{Perspectives on Accountability}

Romzek and Dubnick [26] have suggested four forms of accountability viz. bureaucratic, legal, professional, and political, each of which is associated with a different value emphasis and behavior expectations [31]. Similarly, two dimensions of accountability relationship occur in these four forms [26] [31] [32] [33]. The first dimension is the source of control/expectations and second is the degree of control/autonomy. The source of control/expectations is internal or external and the degree of control/autonomy is either high or low.

Ackerman [28] presents two different variants of accountability, namely accountability as honesty and accountability as performance. According to him, the honesty version is process-oriented, but negative. Duty bearers are evaluated through time and based on the extent to which they abide by the standard operating principles. On the other hand, performance as accountability is results-driven, and positive. It is an emphasis on the outcomes, which are evaluated at project endings. Considering these two variants of accountability, it can be said that honesty of accountability is associated with the rule, while performance of accountability is associated with the pro-active public decision-makers who are expected to perform efficiently and effectively.

Ebrahim and Weisband [34] view accountability differently than Ackerman [28]. According to them, accountability is a combined form of four components viz. transparency that is also mentioned by Koppell [27], answerability or justification, compliance and enforcement or sanctions. Transparency deals with the collection of information and making it available and accessible for public scrutiny. Moreover, answerability or justification is concerned with providing clear reasoning for actions and decisions. On the other hand, compliance should be ensured via monitoring and evaluation of procedures and outcomes, combined with transparency by reporting findings. Last but not least, enforcement or sanctions deal with shortfalls in compliance, justification or transparency of organizations and of duty bearers. Based on the argument made by Ebrahim and Weisband [34], it can be reasoned that these four components are the keys through which duty bearers and organizations can be held accountable for their performance, actions, and behaviors.

Bovens, Schillemans and Hart [16] offer three different normative perspectives-democratic, constitutional and learning-through which accountability can be judged. First, within democratic perspective, accountability measures should effectively link government's actions to the democratic chain of delega- 
tion. Second, in the constitutional perspective, it is essential that accountability arrangements prevent or uncover abuses of public authority. Finally, the learning perspective of accountability, also argued by Aucoin and Heintzman [35], focuses on the learning capacity and effectiveness of the public administration, and encouragement and promotion of learning, in pursuit of continuous improvement in governance. In this perspective, accountability provides the duty bearer and organizations with feedback-based inducements to increase their effectiveness and efficiency [36]. Accountability is seen as a tool that encourages governments, organizations and individual officials, delivering effectively on their promises, with the help of learning, reflection and feedback mechanisms [16]. The central theme is to induce and institutionalize the capacity of public office holders, organizations and the executive branch to learn [37] and to improve efficiency and effectiveness in their performance.

Llyod [38] sees accountability as hardware and software, which is more or less similar to conduct of accountability and accountability of conduct and mechanism and virtue aspect of accountability. Accountability as a hardware, or conduct of accountability, includes structure, procedures and processes within organizations. It is also known as the mechanism of accountability as suggested by Bovens [17]. This view of accountability comes from the British, Australian, Canadian and Continental European scholarly debate [39]. Bovens [17] argued that mechanism of accountability is used in a narrower, as well as in a descriptive sense and especially focuses on the relationship between actors and forums. Actors are held accountable by forums in which they are obligated to explain or justify their conduct and performance. The forum can ask questions, pass judgments and impose consequences on the actor. This is what one could also call passive accountability because actors are held to account by a forum, ex-post facto, for their conduct [17]. Thus, it can be said that hardware or mechanism aspect of accountability does not focus on the behavior of agents, but the way in which these institutional arrangements operate as a principal-agent nexus.

Accountability as software, or accountability of conduct, focuses on the attitude, perception, mindset, behavior and action of the actor. It is also known as the virtue of accountability, as argued by Bovens [17]. The virtue view of accountability emerged mainly from the American academic and political discourse [39]. Bovens [17] argues that accountability as a virtue is difficult to define. According to him, there is no consensus about the standards for accountable behavior. It varies depending on institutional context and political perspective. In this sense, accountability is seen as a positive quality in organizations or officials whose actual behavior is the focus of attention. Hence, it leads to legitimacy of an actor.

These two thoughts of accountability seem contradictory and different in nature, but they supplement each other. The standard behaviors of the actors are highly emphasized in virtue aspect of accountability. An actor should act in a responsive, responsible, transparent, fair, and equitable way. For this, there should be an institutional arrangement between the actor and forum, by which 
they can be held accountable through questions, judgments, and imposition of consequences. This mechanism obliges actors to explain and justify their conduct. As a result, actors successfully accomplish their works in an accountable way.

\subsection{Accountability in the Context of Nepal}

The current concept of accountability has a history as old as civilization itself [40]. However, public accountability in Nepal is comparatively a recent one. Although, historical glimpses reveal that some kings and prime ministers used to rule as per the wishes of the people and tried to elicit public opinion before any decision was taken [41]. During the Rana regime, the entire public service system was made strictly accountable to ensure the interest of ruling family [41]. After the advancement of democracy in 1950, different administrative reforms such as Buch Commission 1952; Acharya Commission 1956; Jha Commission 1968, and Thapa Commission 1975, were set up to initiate several reform efforts to ensure that the bureaucracy was responsive to the public needs. During these periods, several modern government bodies such as the Supreme Court, the Auditor General's Office and the Public Service were set up to ensure accountability in the governance system.

During the Panchayat Regime (1960-1990) the public administration was more loyal and respectful towards the Panchayat rather than public service [42]. After the restoration of democracy in 1990, different government bodies (Commission for the Investigation of Abuse of Authority, National Vigilance Centre, Financial Committee and Public Account Committee) and administrative reforms such as Administrative Reform Commission 1991, Administrative Reform Management Committee 1992, Governance Reform Program 2001, Vision Paper for Civil Service and High-Level Administrative Reform Committee 2014, were set up. The main aim of these government bodies and administrative reforms are to make bureaucracy or public sector governance more dynamic, results-driven, people-oriented, transparent, efficient, effective, competent, prompt, responsive, trustworthy, corruption free, and accountable. The Government of Nepal has adopted, practiced and ensured transparency and accountability in public sector governance through different constitutional bodies, state institutions and by enacting laws, policies, directives, and guidelines as follows:

\subsection{Institutional Frameworks for Accountability in Nepal}

Commission for the Investigation of Abuse of Authority (CIAA) is an apex constitutional body established by the Constitution of Nepal 1992 (Part 12, article 97), aimed to control corruption and investigate against any public officials in case of abuse of authority or improper conduct. It has the legal mandate to act as an ombudsman, investigator, and prosecutor as well. It focuses on preventive, promotional, and punitive measures for combating corruption in public sector governance. It can recommend punishment for the accused based on the degree of corruption or the abuse of authority. If the abuse is proved during investiga- 
tion, a file is registered in court [41]. Hence, it plays a direct or indirect role to hold public officials accountable for their functions, activities, and performance.

National Vigilance Centre was established as a statutory government body in August 2002 by His Majesty's Government of Nepal, under the direct supervision and control of the Prime Minister. It is constituted under the Corruption Prevention Act, 2002 for preventing corruption and raising public awareness on effective service delivery and mismanagement. It conducts surveillance, surprise audits, and inspections in corruption prone places or works. It collects and updates information from authority's bodies and refers to the concerned organization and CIAA for further investigation and prosecution. The Centre plays a preventive role, primarily by monitoring asset declarations of government officials. Therefore, it makes public sector organization transparent and accountable for their performance by minimizing improper conduct and malpractices.

The Office of the Auditor General was established as per the Constitution of the Kingdom of Nepal, 1958 (Part 13, article 99) for promoting accountability, transparency, and integrity for the benefit of the people. Prior to the establishment of Office of the Auditor General, the institution named Kumari Chowk Adda used to review the government accounts. It is a constitutional body that plays a key role in improving and assuring clean practices in the working system of the administrative, financial, and managerial system. It has the power to conduct independent, partial or full audit of public resources for promoting and holding public officials accountable for their performance. It has obliged all secretaries of ministries to submit annual financial statements covering all financial activities of ministries and departments. Thus, it holds the public sector governance transparent and accountable.

The Revenue Investigation Department was formed within the Ministry of Finance under the Revenue (Inspection and Control) Act, 1996, for conducting investigations into revenue leakage and malpractice. The potential for leakage of revenue is divided into: export and import sector, clearance of value-added, and income taxes and transactions involving foreign currency. This department controls and investigates revenue leakages and controls economic crimes; and has also made public authorities accountable in terms of economy and revenue.

The National Investigation Department is an intelligence agency established within the Ministry of Home Affairs to collect information related to the country's public security, economic crimes, corruption in government, and domestic and foreign terrorist activities. This department does not directly involve in checking accountability and controlling corruption; however, it provides information for such purposes.

Public Accounts Committee is constituted as per the provisions of the Constitution and the House of Representative Regulations 1998, for overseeing a different aspect of public services and its accountability in those matters. It is a powerful committee chaired by opposition parties' elected parliamentarian for ensuring public finance accountability in Nepal. It has the legal authority to examine government accounts, public accounts and reports submitted by the Au- 
ditor General, and asks questions in relation to irregularities and corruption to reduce misuse and abuse of public funds. Hence, it holds public sector governance accountable and transparent in their performance.

\subsection{Laws, Policies, Directives, and Guidelines}

For making the Civil Service more capable, vigorous, service oriented, responsible, and accountable, the Government of Nepal promulgated The Civil Service Act 1993 and Rules 1993 [43]. This act and rule have provided clear provision of constitution and operations such as recruitment, transfer, promotion, salary, allowance, medical expenses, training, study, leave, safeguard of service, retirement, gratuity, pension, appeal, and miscellaneous. It has discussed performance evaluation. Zimmermann and Stevens [44] argue that performance measurement/evaluation has been viewed as the newest method of ensuring accountability. A good set of performance measures builds accountability and that improved accountability generates better productivity in the agency [45]. Hence, we can say that The Civil Service Act 1993 and Rules 1993 try to ensure accountability through performance evaluation. Similarly, it has also discussed a code of conduct, punishment, and dismissal from services. All these factors play direct or indirect role in holding civil servants accountable.

The Government of Nepal [45] also promulgated the Local Self-Governance Act in 1999 for devolution of power from central to local level. This act suggested six principles; among them, five directly or indirectly discuss the issues of accountability. This act mentions both public as well as hierarchy accountability. In public accountability, local bodies should be responsible and accountable to the people they serve. This means that local bodies are accountable to those who have no power or less power, such as beneficiaries, service receivers, and so on. In case of hierarchy accountability, the local workforce is accountable to their senior hierarchy of administration. It discusses the chain of command where subordinates usually report to a superior about their actions and performance.

In order to develop local leadership, as per this act, there should be an arrangement of effective mechanism to make the local body accountable to the people in its own areas. It has made provision for the complaint, monitoring, supervision, audit, maintenance of records of books and accounts, and punishment in case of malpractices and improper conduct. Local bodies have the mandate to prepare annual budgets, plans and programs, and submit a report to concerned authorities within a given time period. Although function, role, responsibilities, and authorities are mentioned, this act does not address answerability, delegation, arbitration, and enforceability, all of which are fundamental aspects of accountability principles. Despite this, the Local Self-Governance Act is a milestone legislation that provides an avenue to hold local level authorities responsive and accountable for their actions, functions, decisions, and performance.

The Prevention of Corruption Act 2002 is a milestone that has offered the legal provisions relating to prevention of corruption with a view to maintaining 
peace, convenience, financial discipline, morality, and good conduct [46]. This act does not directly discuss accountability but rather emphasizes it via identification of misconduct and punishment. It has made provision for punishment to public officials for accepting goods or service free of cost or at lower prices, taking gift or donation (without prior approval), taking commission, leaking revenue, preparing and translating false documents, tampering with government documents, damaging government or public documents, giving false particulars and report, engaging in illegal trade or business, claiming false designation, damaging public property, exerting illegal pressures, acquiring property illegally, and so on. Hence, we can say that through this act, the Government of Nepal has tried to make public officials and public-sector organizations responsive, transparent and accountable for their actions and performance.

The Public Procurement Act and Regulation 2007 is a landmark legislation that guides public officials on various issues of procurement [47]. It has made legal provisions to make the procedures, processes, and decisions relating to public procurement of goods and services by state and non-state agencies either through tender or quotation, much more open, transparent, accountable, objective, and reliable. Similarly, it has made legal mandate to prepare procurement plans, cost estimation, goods description, construction works, and services. Hence, it promotes competition, fairness, honesty, reliability, and accountability in public procurement processes. Through this, the Government of Nepal is ensuring public officials and public sector organization remain transparent, open, fair, and accountable in the procurement process.

Realizing information as a tool for democracy and good governance, the Government of Nepal has passed what is called The Right to Information Act 2007 [48]. This act has realized information is a fundamental right of citizens. Every public sector organization has to respect and protect the right to information of the citizen. They have to classify and update information, making it simple, clear, complete, and easily accessible to the public. This act has also clearly emphasized that every public sector conduct their functions openly and transparently. It also requires the arrangement of an information officer for the purposes of disseminating information held in its office. Hence, disclosing information proactively or reactively is seen as a measure of openness that can combat corruption and minimize irregularities or misconduct in public sector organizations. It holds the public sector organizations responsive, transparent, and accountable to citizens.

With the purpose of establishing good governance at all levels, the Government of Nepal has established Good Governance (Management \& Operation) Act in 2008 [49]. This act ensures the basis of good governance, which includes equity and inclusiveness, rule of law, human rights, people centric governance, corruption free, impartiality and neutrality of the administrative mechanism, access for people to the administrative mechanism and its decisions, transparency, accountability and honesty, economic discipline, and so on. Similarly, this 
act has also clearly specified the procedures for executing administrative functions and role and responsibility of all actors of governance and development. These actors are ministers, chief secretaries, secretaries, heads of departments and chief office holders. It has made mandatory provision to keep citizen charter, provide mobile services, determine services fees, participation, set up governance reform unit, public hearing, public audit, citizen report card, managing grievances, pursue information technology in practice, set up monitoring and evaluation committee and submission of annual report by the government agencies. This act has ensured transparency and accountability in all operations of budget, decision-making, and service delivery processes. Based on this, we can say that this act is another milestone that intends to strengthen accountability mechanisms for ensuring good governance at all levels.

In spite of these constitutional bodies, state institutions and laws, policies, directives and guidelines, practices and exercise of accountability has not gone as expected. Consumer Unity and Trust Society [50] argued that violating rule of law, political transition and lack of political will are some of the reasons for low level of accountability. However, some social accountability tools such as public hearing, public audit, community score card, citizen charter, citizen report card, public expenditure tracking survey, community monitoring, and right to information, and many others are being practiced in Nepal.

\subsection{Theoretical Basis}

Accountability is multifaceted and can't be measured by observing single variables. Hence, different proxy indicators are used to examine the practice and exercise of accountability in Nepali bureaucracy. Koppell [27] suggests five different typologies of accountability, which are directly used to examine the scenario of accountability in the Nepali context. As per Koppell [27], transparency and liability can be thought of as foundations, while the remaining three (controllability, responsibility, and responsiveness) can be thought of as substantive. Transparency is key to the accountability process and makes an actor obligated to provide, explain, and justify information about their activities to the forum. If the actor discloses facts related to performance or activities, then we can say that he/she is transparent, which in turn helps in accountability. Liability is another typology of accountability without which accountability is meaningless [51]. Liability deals with consequences (reward and punishment), which are attached to the performance of the actor. In other words, the actor should be held answerable for their actions; they are punished for malfeasance and rewarded for success. If an actor faces consequences for their performance, then we can say that there is accountability.

The third typology of accountability is controllability. It deals with the authority and control of the behavior or action of the actor. This means that an actor is constrained by the orders of forum. If the forum can induce the behavior or action of an actor, the forum controls the actor. As a result, actor is accounta- 
ble to the forum. If an actor follows through with what its forum has ordered, then there is controllability. This means that there is evidence of accountability.

The fourth typology of accountability that constrains actors by formal and informal professional standards or behavior such as laws, rules, and norms, is labeled responsibility. Such standards may encourage better behavior and set expectations against which the actor can be evaluated [52] [53] [54]. Friedrich (n.d. cited in Koppell [27]) argues that an accountable actor should not simply follow orders, as we mentioned in controllability, but must use their expertise constrained by professional and moral standards. If the actor follows well-established rules, then we can say that he/she is responsible. The final typology of accountability that satisfies the demands and needs of clients is considered to be responsiveness. In this typology, accountability turns outward rather than upward [27]. That is why it is also called customer-oriented approach and bottom-line vision of accountability. If actor fulfills the demand and need of the forum, then we can say that he/she is a responsive actor. The responsive actor means there is evidence of accountability. Hence, for us, accountability is combined form of transparency, liability, controllability, responsibility, and responsiveness. In this study, we used this as a theoretical basis of accountability.

\section{Methodology}

\section{Econometrics}

This present study of accountability employs a quantitative approach, which is based on the post-positivist paradigm [55]. Post-positivism paradigm assumes that there is single or objective reality. Hence, reality about accountability in Nepali bureaucracy is single or objective which is measurable and quantifiable. For this, we utilized deductive approach and survey as a strategy of inquiry. In this process, we applied descriptive as well as explanatory research designs. Descriptive research design was applied to find out the exact level of accountability and explanatory research design to examine to what extent accountability is differ by demographics of bureaucrats.

Our target population for the survey was bureaucrats working in central level organizations of the Ministry of Education. According to the records of the Ministry of Education dated 2017/08/31, the total number of posts (Darbandi) was 592 across different central level organizations. In this study, we excluded rank-less employees (Shreni Behin Karmachari) and vacant post (Rikta Pad) from my sampling frame. Hence, the total number of bureaucrats working in the central level organizations of the Ministry of Education was 459. The selection of samples from the population without using any appropriate sampling technique cannot represent the population perfectly. Hence, we used probabilistic sampling technique. This technique ensures the external validity in our study. The question can be raised about the appropriate size of the sample. To address this, Yamane [56] proposed the most popular and widely accepted formula to select a representative sample from the population. Symbolically: 


$$
n=\frac{N}{1+N \times e^{2}}
$$

where,

$$
n=\text { sample size }
$$

$N=$ total number of population

$e=$ standard error (sometimes also called interval/margin of errors or level of significance/precision)

Based on Yamane's formula, we determined the actual sample size. We assumed 95\% confidence level and maximum 5\% interval/margin of errors. The $95 \%$ confidence level of our study indicates that when the population is repeatedly sampled, 95 out of 100 times would have true population value. As per the formula, 213 samples are required to represent the population perfectly. The calculation procedure is as follows:

$$
\begin{gathered}
n=\frac{459}{1+459 \times(0.05)^{2}} \\
n=\frac{459}{1+459 \times 0.0025} \\
n=\frac{459}{1+1.1475} \\
n=213
\end{gathered}
$$

Hence, the sample size of our study is 213 individual bureaucrats, which are the unit of analysis of our study.

We designed self-administered structured questionnaire as a means of data collection which entails information of accountability based on transparency, controllability, liability, responsibility, and responsiveness as suggested by Koppell [27]. We finalized this questionnaire after having series of meetings with peers, examiners, and subject experts in the field of accountability. After this, we translated the questionnaire into the Nepali language and conducted a pre-test to check reliability of the questionnaire. While revising the questionnaire based on the pre-test, we analyzed each item by determining difficulty level. Finally, we collected the data by using the pre-tested questionnaire in office hours (10:00 am-4:00 pm).

After collecting the primary data, we examined and cleaned them to make suitable for the econometric estimation and relevant analysis. During this process, we scrutinized, coded (code book) and recoded, and entered data into Statistical Package for the Social Sciences software program to obtain the required information. We analyzed the data by using descriptive and inferential statistics as well after following the standard data exclusion criteria. In descriptive statistics, we calculated frequency, percentages, crosstab and median. In inferential statistics, we used Rank-correlation, Chi-square, and Logistic regression. Rank-correlation and Chi-square was used to check the association and independence between two variables. Binary logistic regression was used to estimate the probability of the event occurring and variation in dependent variable 
with or without statistically significant. For this, dependent variable (accountability) was categorized in two different forms-being accountable (coded as " 1 ") and not being accountable (coded as "0").

Demographic characteristics of bureaucrats-gender, age, education, service year, and position were considered as independent variables. Probability of being or not being accountable is compared against each reference category of each demographic characteristic of bureaucrats. The Logistic Regression Equation: $\ln [P /(1-P)]=\alpha+\beta X+€$. Where, $P$ is the probability that an event $\mathrm{Y}$ occurs; $(1-P)$ is the probability that an event does not occur; $\alpha=$ the constant of the equation; $\beta=$ the coefficient of the predictor variables; $P /(1-P)$ is the "Odds Ratio"; $\ln [P /(1-P)]$ is the log odds ratio, or "logit". In this study, $P$ is the probability of being accountable and $\beta X$ is the demographics-gender, age, education, service year and position of bureaucrats. We can write the model in terms of odds as: $P /(1-P)=\exp (\alpha+\beta X)$. Probability of the outcome (e.g. being accountable) occurring is $P=\exp (\alpha+\beta X) /(1+\exp (\alpha+\beta X))$. Conversely, the probability of the outcome not occurring (e.g. not being accountable) is $1-P=1 /[1+\exp (\alpha+\beta X)]$. The slope represents the ratio of the probability of being accountable to the probability of not being accountable compared against each reference category of each background characteristic of bureaucrats.

\section{Results}

To examine the level of accountability bureaucrats, we adopted five typologies (transparency, liability, control, responsibility, and responsiveness) of accountability, as suggested by Koppell [27]. Based on these typologies, we calculated the level of accountability by using median, which are as follows:

\subsection{Accountability and Gender}

The median value of accountability is 4 , which indicates that there is a higher level of accountability of bureaucrats. By gender, female bureaucrats have a slightly higher level of accountability than male. If data is segregated by accountability typologies, the value of responsibility is higher than other typologies. Except for controllability and liability, all components have more than 4 median values. This means that there is no strong internal and external control mechanism to hold bureaucrats accountable. Similarly, it also indicates that there is no provision or a very weak provision of reward and punishment in bureaucracy. By gender, female bureaucrats were found to have slightly higher controllability, liability, and responsiveness than males. However, male bureaucrats had slightly higher transparency and responsibility than female bureaucrats. This indicates that accountability and its typologies differ by gender of bureaucrats (Figure 1).

\subsection{Accountability and Age}

We believed that accountability and its typologies also differ by age of educational bureaucrats. To confirm this, we calculated a crosstab, which is presented in Figure 2. The data shows that all age groups have more or less similar levels 


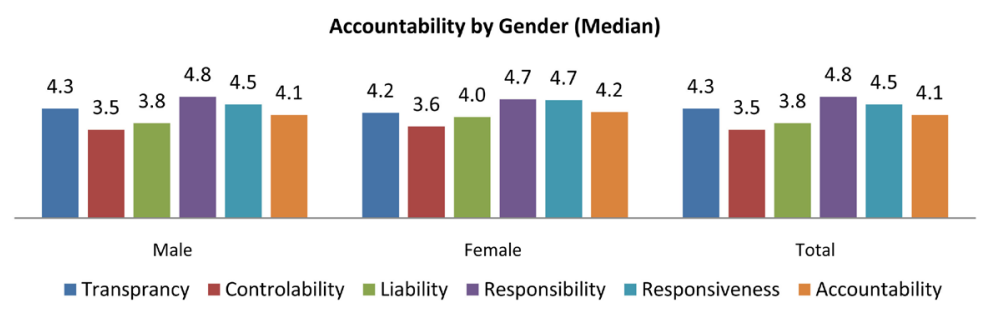

Figure 1. Level of accountability by gender.

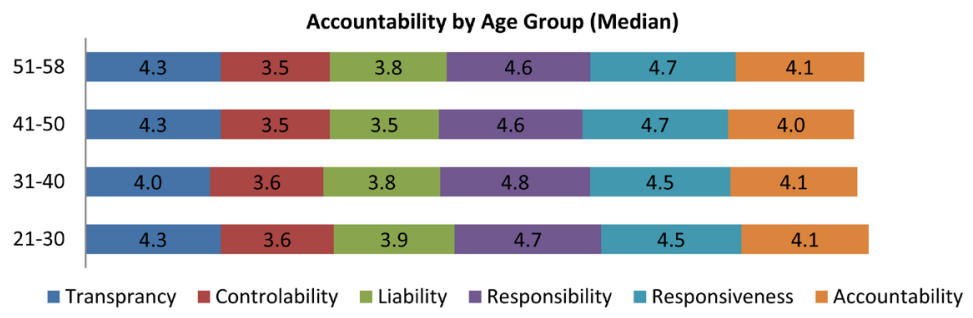

Figure 2. Level of accountability by age group.

of accountability. If data are segregated by accountability typologies, the median value of transparency was higher in all age groups except 31 - 40. Age group 21 30 and $31-40$ had a higher level of controllability than $41-50$ and $51-58$. However, this scenario is completely different in case of responsiveness. Age group 21 - 30 and 31 - 40 had a lower level of responsiveness than $41-50$ and 51 - 58. In case of liability, age group 21 - 30 had higher liability median value than others, while a higher median value of responsibility was observed in the age group $31-40$, than in the others. This evidence clearly indicates that typologies of accountability differ by age of educational bureaucrats (Figure 2).

\subsection{Accountability and Education}

It is very hard to say that level of accountability and its typologies differ by level of education of bureaucrats. To check this, we calculated a crosstab, which is presented in Figure 3. It is clear from the table that the level of accountability of bureaucrats increased by their level of education. By accountability typologies, median value of transparency and responsiveness follow same as accountability. Similarly, controllability and liability also follow same as transparency and responsiveness, except in Master degree category. From this evidence, it can be said that there is a positive relationship between the level of education and level of accountability and its typologies (except responsibility). However, this case is completely different in regards to responsibility. Level of responsibility decreased by increasing level of higher education, except for Master degree respondents. Thus, it was found that accountability and its typologies differed by education level of bureaucrats (Figure 3).

\subsection{Accountability and Position}

The role of position in accountability cannot be ignored. Bearing this in mind, we calculated a crosstab, which is presented in Figure 4. All positions were 


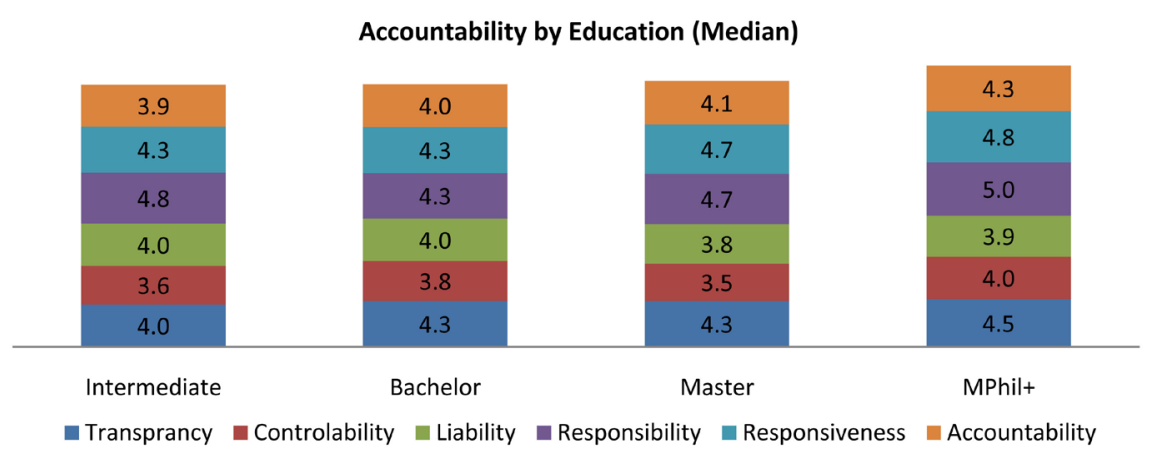

Figure 3. Level of accountability by education.

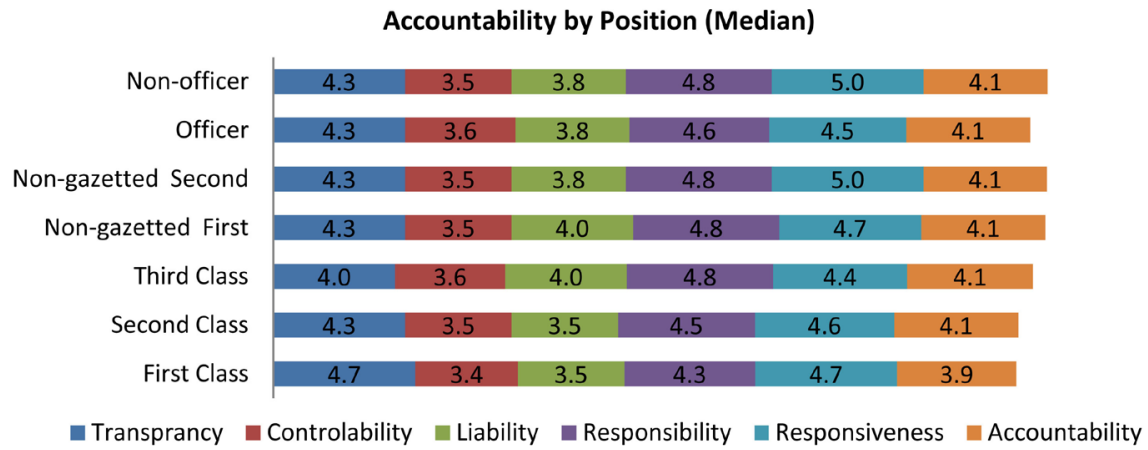

Figure 4. Level of accountability by position.

found to have more or less similar levels of accountability. Higher median value of accountability was observed for class three and was found to gradually decrease by increasing position. Similar levels of accountability were also observed for non-gazetted first and non-gazetted second. Further, we classified position in two broad categories including gazetted and non-gazetted bureaucrats. It is interesting to note that similar median value of accountability was observed for gazetted and non-gazetted. By typologies, the higher median value of transparency and responsiveness was observed for class first and was found to gradually decrease up to class three. However, higher median value of controllability, liability, and responsibility was seen for class three and found to gradually decrease with increase in position. Gazetted bureaucrats had a lower median value responsiveness and responsibility than non-gazetted. From this, it can be said that accountability and its typologies differ by the position of educational bureaucrats (Figure 4).

\subsection{Accountability and Service Year}

Similar to age, we also believed that accountability and its typologies differed by service year of educational bureaucrats. To support this argument, we calculated another crosstab, which is presented in Figure 5. All service years of bureaucrats were found to have more or less similar levels of accountability. The median value of accountability was 4 in all service years, except $11-15$ year (median value 3.9), which indicates there is a higher level of accountability of bureaucrats. 


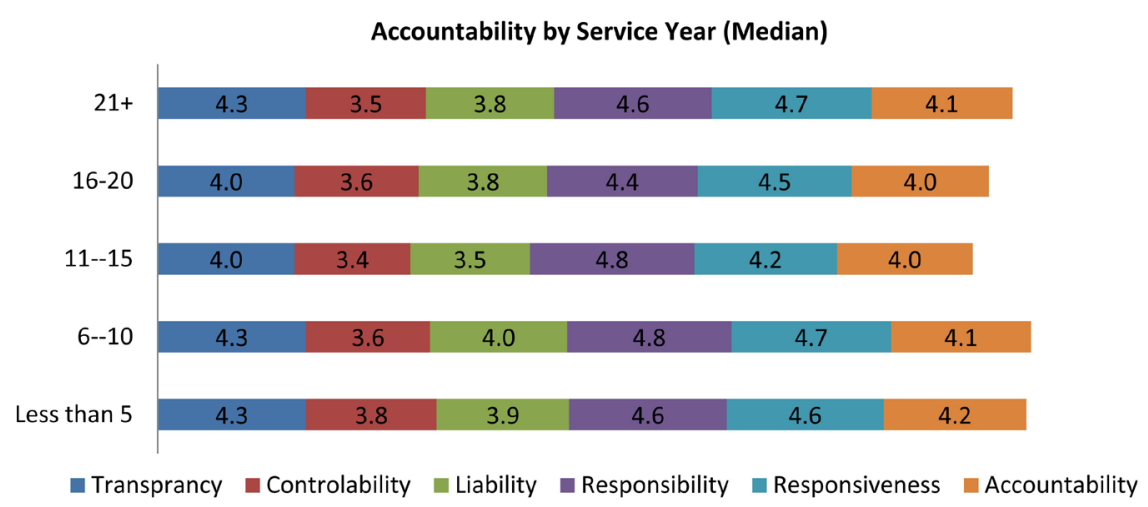

Figure 5. Level of accountability by service year.

If data is segregated by accountability typologies, the median value of transparency, controllability, liability, responsibility, and responsiveness are higher in all service years except 11 - 15. Higher median value of controllability was observed for service years less than 5 years, while higher liability value was observed for 6 - 10 service years. Higher median value of responsibility was observed for $6-10$ and $11-15$ service years, and this scenario is slightly different for responsiveness. Service years $6-10$ and $21+$ had higher responsibility values. Thus, it can be noted that accountability and its typologies differed by service year of educational bureaucrats (Figure 5).

\subsection{Correlation and Independence Analysis}

We analyzed the question regarding whether accountability of educational bureaucrats is linked with their demographic characters or not. For this, we applied Spearman's Correlation and Chi-Square test. The Spearman's Correlation Coefficient value of accountability and demographics of bureaucrats ranged from 0.004 to 0.119 . The value of Spearman's rho clearly indicated a very weak positive (except service year, $\mathrm{r}=-0.048$ ) association between accountability and demographics of bureaucrats. Notice that this correlation is marked as not significant because the value of significance was reported to be greater than 0.05 (at the $95 \%$ level of confidence), which was also confirmed by significance value of Chi-Square. This result suggests that there is no statistically significant difference between accountability and demographic characters of bureaucrats. That is why; we can say that accountability and demographic of bureaucrats are independent (Table 1).

\subsection{Regression Analysis}

Table 2 provides the regression coefficient beta $(\beta)$, the Wald statistic (to test the statistical significance) and the all-important Odds Ratio $[\operatorname{Exp}(\beta)]$ for each variable category. From this evidence, it is interesting to note that demographics do not significantly contribute to accountability because significant values of all demographic variables are more than 0.05 . Based on these results, we can conclude that demographics have less or no effect on accountability (Table 2). 
Table 1. Correlation and chi-square for accountability and demographics.

\begin{tabular}{ccccccc}
\hline & \multicolumn{2}{c}{ Accountability } & \multicolumn{3}{c}{ Chi-Square } \\
\cline { 2 - 3 } Demographics & \multicolumn{2}{c}{ Correlations (Spearman's rho) } & & & \\
\cline { 2 - 5 } & $\begin{array}{c}\text { Correlation } \\
\text { Coefficient }\end{array}$ & $\begin{array}{c}\text { Sig. } \\
(2-\text {-tailed) }\end{array}$ & Value & df & $\begin{array}{c}\text { Asymp. Sig. } \\
\text { (2-tailed) }\end{array}$ \\
\hline Gender & 0.119 & 0.084 & $3.610^{\mathrm{a}}$ & 2 & 0.165 \\
Age & 0.004 & 0.959 & $5.262^{\mathrm{b}}$ & 6 & 0.511 \\
Education & 0.112 & 0.102 & $4.014^{\mathrm{c}}$ & 6 & 0.675 \\
Position & 0.081 & 0.240 & $7.322^{\mathrm{d}}$ & 8 & 0.502 \\
Service Year & -0.048 & 0.490 & $11.279^{\mathrm{e}}$ & 8 & 0.186 \\
\hline
\end{tabular}

Table 2. Coefficients of logistic regression for accountability by demographics.

\begin{tabular}{|c|c|c|c|c|c|c|}
\hline Demographics & B & S.E. & Wald & df & Sig. & $\operatorname{Exp}(B)$ \\
\hline \multicolumn{7}{|c|}{ Gender } \\
\hline \multicolumn{7}{|l|}{ Male (Reference) } \\
\hline Female & 0.859 & 0.409 & 4.408 & 1 & 0.036 & 2.361 \\
\hline \multicolumn{7}{|c|}{ Age group } \\
\hline \multicolumn{7}{|l|}{21 - 30 (Reference) } \\
\hline $31-40$ & 0.513 & 0.584 & 0.772 & 1 & 0.380 & 1.671 \\
\hline $41-50$ & 0.971 & 0.674 & 2.074 & 1 & 0.150 & 2.641 \\
\hline $51-58$ & 1.276 & 0.753 & 2.876 & 1 & 0.090 & 3.584 \\
\hline \multicolumn{7}{|c|}{ Education } \\
\hline \multicolumn{7}{|l|}{ Intermediate(Reference) } \\
\hline Bachelor & 1.164 & 1.105 & 1.109 & 1 & 0.292 & 3.201 \\
\hline Master & 1.382 & 1.043 & 1.756 & 1 & 0.185 & 3.984 \\
\hline MPhil+ & 2.093 & 1.255 & 2.782 & 1 & 0.095 & 8.113 \\
\hline \multicolumn{7}{|c|}{ Position } \\
\hline \multicolumn{7}{|l|}{ First Class (Reference) } \\
\hline Second Class & 1.102 & .936 & 1.386 & 1 & 0.239 & 3.011 \\
\hline Third Class & 1.144 & .922 & 1.540 & 1 & 0.215 & 3.139 \\
\hline Non Gazetted First & 1.963 & 1.005 & 3.815 & 1 & 0.051 & 7.119 \\
\hline Non Gazetted Second & 1.719 & 1.038 & 2.743 & 1 & 0.098 & 5.582 \\
\hline \multicolumn{7}{|c|}{ Service Year } \\
\hline \multicolumn{7}{|l|}{ Less than 5 (Reference) } \\
\hline $6-10$ & -0.066 & 0.567 & 0.014 & 1 & 0.907 & 0.936 \\
\hline $11-15$ & 0.147 & 0.603 & 0.059 & 1 & 0.807 & 1.158 \\
\hline $16-20$ & 0.082 & 0.601 & 0.019 & 1 & 0.891 & 1.086 \\
\hline $21+$ & 0.122 & 0.652 & 0.035 & 1 & 0.852 & 1.129 \\
\hline
\end{tabular}




\section{Discussion}

Accountability in individual staff is considered as a key element to improve the government's delivery to the people. Hence, it is a sign of good governance. Good governance can be achieved in bureaucracy, including in educational bureaucracy, through accountability. As per results of the present study, educational bureaucrats who are working in the central level organizations of the Ministry of Education seem to be accountable. This might be an effect of constitutional bodies, state institutions, laws, policies, directives and guidelines that were formed for enhancing level of accountability. They are obligated to explain, answer, justify, and defend their actions and performance. Generally, people believe that the level of accountability varies according to demographic variables. In this study, descriptive statistics also supports the argument. However, inferential statistics did not produce a significant effect. From this, we can say that accountability and demographics of educational bureaucrats are independent. Accountability of educational bureaucrats is dependent on transparency, liability, controllability, responsibility, and responsiveness. Transparency and liability can be considered as foundations, whereas the rest (controllability, responsibility and responsiveness) can be taken as substantives [27].

\subsection{Transparency}

In the present context, transparency is considered as a key tool of good governance and a prerequisite to any democratic regime [57]. Transparency means the free flow of information and its availability to all those who are connected with the decisions [58]. It is a dominant force in the bureaucratic structure that helps to counter corruption, improve governance and promote accountability. The results of the study show that the central levels of educational bureaucrats seem to be transparent. They are disclosing and disseminating information to respective forums proactively through the website, press release, annual report, and so on, and reactively through spokesperson and information officers. Hence, educational bureaucrats are informing and reporting to the forum about their conduct and performance, as argued by Bovens [17]. Similarly, we believed disclosure of complete and reliable information, whether proactively or reactively, is necessary but not a sufficient condition for accountability. Information must be accessible for the forum, which is vital for accountability [59]. This is because information available to the forum is an essential first step leading to increased accountability. Hence, information should be accessible to all forums. Educational bureaucrats are making information accessible to relevant forums upon request, as well as, proactively. Therefore, transparency generates accountability [60] in Nepali bureaucracy. Along the same lines as Fox, Meijer [61] argues that transparency can facilitate and strengthen horizontal and vertical accountability. This is because a more informed forum can play a meaningful role in dialogue with their actors. Thus, it is seen as a measure of openness that combats corruption and minimizes irregularities or misconduct by actors. This might be an ef- 
fect of The Right to Information Act 2007. This act recognizes information as a fundamental democratic right of the citizen. Every public-sector organization has to respect and protect the right to information of the citizen.

\subsection{Liability}

Transparency is necessary but far from sufficient to produce accountability [60]. Along with transparency, liability is required. Accountability, eventually, can be understood as liability [62]. Thus, accountability without liability is meaningless [51]. That might be the reason that Koppell [27] argues that liability can be taken as a foundation of accountability. As per Bovens [17], the actor should face consequences. Hence, answerability without consequences falls short of accountability [60]. Actors are held liable for their activities, punished for malfeasance and rewarded for successes [27]. Therefore, reward and punishment system is associated with accountability [63]. The Government of Nepal has formed different laws, policies, code of conduct, constitutional bodies, and state institutions for ensuring liability of the actor. However, results of the study show that there is a weak mechanism of reward and punishment within educational bureaucracy. The Civil Service Act 1993 and Regulation 1993 has clearly mentioned that bureaucrats should be punished and dismissed from services for their misconduct. However, in practice there is no strong punishment and reward mechanism for bad and good performance. This might be an effect of sycophancy and patron-client relation in Nepali bureaucracy.

\subsection{Controllability}

Control is too strong a term for the accountability relationship when the bureaucracy has become an important component of good governance as the administrative state developed [64]. Hence, accountability is not only related to transparency and liability, but also related to controllability. Controllability refers to the existence of mechanisms to sanction actions and decisions that run counter to given mandates and procedures [65]. It deals with the authority and controls the forum over the behavior or action of the actor. This means that the actor is controlled by the orders of the forum. Controllability adds transparency, credibility, and reliability in the process of accountability [66]. This mechanism discourages actors to misuse authority, power, position and resources. Actors should not be held accountable for actions over which they have no control [67] [68]. Hence, there should be external and internal control systems to ensure accountability. However, evidence shows that there is a weak internal and external controllability mechanism in Nepali educational bureaucracy. It indicates that there is no strong system of directing, regulating, supervising, monitoring, advising, inspecting, evaluating and monitoring of external agencies. However, there is a hierarchical control in Nepali bureaucracy. Subordinates usually report to and follow commands of superiors, as argued by Weber [69]. Actions of educational bureaucrats are closely controlled by superiors. Hence, there is formal 
and unambiguous hierarchy control in Nepali educational bureaucracy. From this, it can be said that performance and actions of bureaucrats is controlled by the superior who has different sources, forms, and degrees of power.

\subsection{Responsibility}

Accountability is understood as a synonym of responsibility [24]. Responsibility refers to the obligation of an actor to perform tasks in alignment with the roles assigned [62]. It is one of the important substantives for accountability. Behavior and performance of actor is constrained by formal and informal professional standards. Such standards may encourage better behavior and set expectations against which the actor can be evaluated [52] [53] [54]. Friedrich (n.d. cited in Koppell [27]) argues that accountable actors should not simply follow orders but should use their expertise constrained by professional and moral standards. Responsibilities might stem from formal or informal rules, compliance with standards or procedures, professional norms or from the organizational work process [70]. Every bureaucratic organization has certain rules and regulations that must be followed by bureaucrats to be accountable. That is why Weber [69] argued that bureaucrats should exercise authority delegated to him/her in accordance with formal and predefined rules. Central levels of educational bureaucrats seem more responsible. It clearly indicates that they are following predefined rules, regulations, and processes to accomplish duties. Therefore, many of us feel and perceive that bureaucracy is rule and process-oriented. All the activities and performance are directly guided by rules and regulation, as argued by Weber [69]. Hence, bureaucrats are bounded by the rules, which contribute to ensure accountability in Nepali bureaucracy.

\subsection{Responsiveness}

Responsiveness satisfies the demand and need of citizens. That is why Koppell [27] argues that responsiveness emphasizes on outward rather than upward linkages. It is also called customer-oriented approach and bottom-line vision of accountability. An actor has an obligation to fulfill the demand and need of the forum. A responsive actor should have informing, listening, and responding qualities. The result of the study shows that educational bureaucrats are responsive. This indicates that they are informing citizens about procedures of service as per the demand. Similarly, they listen to all the needs, demands, and concerns of citizens, as well as show sincere interest in solving public problems within the promised time. As such, we can say that educational bureaucrats are responsive, which contributes to ensure accountability in educational bureaucracy.

Overall, our findings lie in line with the findings of Paudel \& Shrestha [9] that states the labor force have not contributed in the overall development of the country. This might be due to the fact that they need to be more accountable improving the quality fulfilling the liability and strong mechanism of the controllability in the entire bureaucratic system. 


\section{Conclusion}

Accountability is an important apparatus for ensuring the quality of the bureaucrats and maintaining good governance in the governments' delivery system. It encourages bureaucrats to take account of their action and performance. In favor of this background, the Government of Nepal has formed different constitutional bodies, state institutions and laws, policies, directives, guidelines, and implemented different tools such as public hearing, public audit, citizen charter, right to information, codes of conduct, performance evaluation and feedback systems, chain of hierarchical command, supervision, inspections, surveillance, monitoring, and reporting to confirm accountability within Nepali bureaucracy. Therefore, educational bureaucrats who are working in central level organizations of Ministry of Education seem to be accountable. Accountability cannot be simply achieved. Different factors such as transparency, liability, controllability, responsibility, and responsiveness play vibrant roles. As suggested by our results, Liability and controllability in educational bureaucracy were not more satisfactory than transparency, responsibility, and responsiveness. Regarding association of accountability and demographics of educational bureaucrats, this study concludes that they are independent.

\section{Acknowledgements}

Authors are thankful to the comments and suggestion from the participation of the seminar held in Kathmandu University, Nepal. Particularly, the comments and feedback by Dr Prakash Bhattarai, Professor Govinda Dhakal, and Professor Mahesh Nath Parajuli were very helpful to improve the quality of this paper. However, the authors are responsible for any errors and mistakes left in the paper.

\section{Conflicts of Interest}

The authors declare no conflicts of interest regarding the publication of this paper.

\section{References}

[1] Wang, X. (2002) Assessing Administrative Accountability: Results from a National Survey. The American Review of Public Administration, 32, 350-370. https://doi.org/10.1177/0275074002032003005

[2] Siddiquee, N.A. (1999) Bureaucratic Accountability in Bangladesh: Challenges and Limitations. Asian Journal of Political Science, 7, 88-104. https://doi.org/10.1080/02185379908434149

[3] Shakya, U.R. (2009) Ethics in Nepalese Civil Services Sector: How Does It Matter? Administration and Management Review, 21, 88-107.

[4] Bajpai, A. (2014) Public Value' as a Normative Framework: A Comparative Evaluation and Recasting of Administrative Culture in India and Nepal. 23rd Congress of International Political Science Association (IPSA), Montreal, Canada, 2014, 1-20.

[5] Dangal, R. (2005) Administrative Culture in Nepal: Does It Reflect the Dominant 
Socio-Cultural Values of Nepal? Unpublished Master's Dissertation, University of Bergen, Bergen.

[6] Bhattarai, P.C. (2017) Reform in Public Service Delivery in Nepal: Demand or Supply Driven? OCED Global Anti-Corruption and Integrity Forum, Paris, 2017, $1-12$.

https://www.oecd.org/cleangovbiz/Integrity-Forum-2017-Bhattarai-public-servicenepal.pdf

[7] Nepal Administrative Staff College [NASC] (2018) Nepal National Governance Survey 2017/18. Nepal Administrative Staff College, Lalitpur.

[8] National Planning Commission (2002) Tenth Plan (2002-2007). Author, Kathmandu.

[9] Paudel, R.C. and Shrestha, M.B. (2006) The Role of External Debt, Total Trade and Labor Force in Economic Growth: The Case of Nepal. The Business Review, 5, 130-136.

[10] Kearns, K.P. (1996) Managing for Accountability: Preserving the Public Trust in Public and Nonprofit Organizations. Jossey-Bass, San Francisco.

[11] Edwards, M. and Hulme, D. (1996) Beyond the Magic Bullet: NGO Performance and Accountability in the Post-Cold War World. Kumarian Press, West Hartford.

[12] Mulgan, R. (2000) Accountability: An Ever-Expanding Concept? Public Administration, 78, 555-573. https://doi.org/10.1111/1467-9299.00218

[13] Behn, R.D. (2001) Rethinking Democratic Accountability. Brookings Institution Press, London.

[14] Ebrahim, A. (2003) Accountability in Practice: Mechanisms for NGOs. World Development, 31, 813-829. https://doi.org/10.1016/S0305-750X(03)00014-7

[15] Bovens, M. (2005) The Concept of Public Accountability. In: Ferlie, E., Lynn Jr., L.E. and Pollitt, C., Eds., The Oxford Handbook of Public Management, Oxford University Press, Oxford, 182.

[16] Bovens, M., Schillemans, T. and Hart, P.T. (2008) Does Public Accountability Work? An Assessment Tool. Public Administration, 86, 225-242. https://doi.org/10.1111/j.1467-9299.2008.00716.x

[17] Bovens, M. (2010) Two Concepts of Accountability: Accountability as a Virtue and as a Mechanism. West European Politics, 33, 946-967. https://doi.org/10.1080/01402382.2010.486119

[18] Blind, P.K. (2011) Accountability in Public Service Delivery: A Multidisciplinary Review of the Concept. Expert Group Meeting Engaging Citizens to Enhance Public Sector Accountability and Prevent Corruption in the Delivery of Public Services, Vienna, 1-8.

[19] Pollitt, C. and Hupe, P. (2011) Talking about Government: The Role of Magic Concepts. Public Management Review, 13, 641-658. https://doi.org/10.1080/14719037.2010.532963

[20] Dubnick, M.J. and Frederickson, G.H. (2011) Public Accountability: Performance Measurement, the Extended State, and the Search for Trust. The Kettering Foundation, Washington DC.

[21] Olsen, J.P. (2013) The Institutional Basis of Democratic Accountability. West European Politics, 36, 447-473. https://doi.org/10.1080/01402382.2012.753704

[22] Ebrahim, A. (2010) The Many Faces of Nonprofit Accountability. In: Renz, D. and Herman, R.D., Eds., The Jossey-Bass Handbook of Nonprofit Leadership and Management, John Wiley \& Sons, Hoboken, 101-121. 
[23] Frølich, N. (2011) Multi-Layered Accountability: Performance-Based Funding of Universities. Public Administration, 89, 840-859. https://doi.org/10.1111/j.1467-9299.2010.01867.x

[24] O’Kelly, C. and Dubnick, M. (2014) Accountability and its Metaphors: From Forum to Agora and Bazaar. Conferencia Anual De 2015 EGPA, 24-29 Agosto 2015, Toulouse, Francia, PSG VII track, 1-25. https://pure.qub.ac.uk/ws/files/13032528/COK_MJD_EGPA_Paper.pdf

[25] Bovens, M., Goodin, R.E. and Schillemans, T. (2014) The Oxford Handbook Public Accountability. Oxford University Press, London. https://doi.org/10.1093/oxfordhb/9780199641253.013.0012

[26] Romzek, B.S. and Dubnick, M.J. (1987) Accountability in the Public Sector: Lessons from the Challenger Tragedy. Public Administration Review, 47, 227-238. https://doi.org/10.2307/975901

[27] Koppell, J.G. (2005) Pathologies of Accountability: ICANN and the Challenge of Multiple Accountabilities Disorder. Public Administration Review, 65, 94-108. https://doi.org/10.1111/j.1540-6210.2005.00434.x

[28] Akerman, J. (2005) Social Accountability in the Public Sector: A Conceptual Discussion, Social Development Papers, Participation, and Civic Engagement. World Bank, Washington DC.

[29] Sirker, K. (2006) General Social Accountability Concepts and Tools. World Bank Institute, Washington DC.

[30] Mulgan, R. (2003) Holding Power to Account: Accountability in Modern Democracies. Springer, London. https://doi.org/10.1057/9781403943835

[31] Romzek, B.S. and Ingraham, P.W. (2000) Cross Pressures of Accountability: Initiative, Command, and Failure in the Ron Brown Plane Crash. Public Administration Review, 60, 240-253. https://doi.org/10.1111/0033-3352.00084

[32] Radin, B.A. and Romzek, B.S. (1996) Accountability Expectations in an Intergovernmental Arena: The National Rural Development Partnership. The Journal of Federalism, 26, 59-81. https://doi.org/10.1093/oxfordjournals.pubjof.a029855

[33] Romzek, B.S. (2000) Dynamics of Public Sector Accountability in an Era of Reform. International Review of Administrative Sciences, 66, 21-44. https://doi.org/10.1177/0020852300661004

[34] Ebrahim, A. and Weisband, E. (2007) Global Accountabilities. Cambridge University Press, Cambridge. https://doi.org/10.1017/CBO9780511490903

[35] Aucoin, P. and Heintzman, R. (2000) The Dialectics of Accountability for Performance in Public Management Reform. International Review of Administrative Sciences, 66, 45-55. https://doi.org/10.1177/0020852300661005

[36] Bovens, M. (2007) Analyzing and Assessing Accountability: A Conceptual Framework. European Law Journal, 13, 447-468. https://doi.org/10.1111/j.1468-0386.2007.00378.x

[37] Argyris, C. and Schon, D. (1978) Organizational Learning: A Theory of Action Approach. Addison Wesley, Reading.

[38] Lloyd, R. (2008) Promoting Global Accountability: The Experiences of the Global Accountability Project. Global Governance: A Review of Multilateralism and International Organizations, 14, 273-281. https://doi.org/10.1163/19426720-01403003

[39] Onzima, B. (2013) Public Accountability: Explaining Variation across Local Governments in Uganda. Unpublished Master's Dissertation, University of Bergen, Bergen. 
[40] Gray, A. and Jenkins, B. (1993) Codes of Accountability in the New Public Sector. Accounting, Auditing \& Accountability Journal, 6, 52-67. https://doi.org/10.1108/09513579310042560

[41] Pradhan, G.B.N., Shrestha, P.L. and Joshi, G. (1995) Administrative Accountability in Nepal. In: Salleh, S.H. and Iqbal, A., Eds., Accountability: The Endless Prophecy, Syarikat Press, Kuala Lumpur, 253-292.

[42] Ghimire, B. and Ashraf, M. (2016) Beleaguered Administration: A Study of Administrative Reforms in Nepal. International Journal of Development Research, 6, 7966-7972.

[43] Government of Nepal (GoN) (1993) Civil Service Act and Regulation 1993. Author, Kathmandu.

[44] Zimmermann, J.A.M. and Stevens, B.W. (2006) The Use of Performance Measurement in South Carolina Nonprofits. Nonprofit Management and Leadership, 16, 315-327. https://doi.org/10.1002/nml.109

[45] Ammons, D.N. (2007) Performance Measurement: A Tool for Accountability and Performance Improvement. School of Government, Chapel Hill.

[46] GoN (2002) The Prevention of Corruption Act 2002. Author, Kathmandu.

[47] GoN (2007) Public Procurement and Regulation 2007. Author, Kathmandu.

[48] GoN (2007) Right to Information Act 2007. Author, Kathmandu.

[49] GoN (2008) Good Governance Act 2008. Author, Kathmandu.

[50] Consumer Unity and Trust Society (2013) Understanding the Context of Nepal for Social Accountability Interventions. M.S. Printer, Jaipur.

[51] Dayanandan, R. (2013) Good Governance Practice for Better Performance of Community Organization-Myths and Realities. Journal of Power, Politics \& Governance, 1, 10-26.

[52] Dilulio Jr., J.D. (1994) Principled Agents: The Cultural Bases of Behavior in a Federal Government Bureaucracy. Journal of Public Administration Research and Theory, 4, 277-318.

[53] Kearney, R.C. and Sinha, C. (1988) Professionalism and Bureaucratic Responsiveness: Conflict or Compatibility? Public Administration Review, 48, 571-579.

https://doi.org/10.2307/975521

[54] McKinney, J.B. (1981) Process Accountability and the Creative Use of Intergovernmental Resources. Public Administration Review, 41, 144-150. https://doi.org/10.2307/975457

[55] Creswell, J. (2013) Research Design: Qualitative, Quantitative, and Mixed Methods Approaches. Sage Publications, New Delhi.

[56] Yamane, T. (1967) Statistics: An Introductory Analysis. 2nd Edition, Harper and Row, New York.

[57] Mabillard, V. and Zumofen, R. (2017) The Complex Relationship between Transparency and Accountability: A Synthesis and Contribution to Existing Frameworks. Public Policy and Administration, 32, 110-129. https://doi.org/10.1177/0952076716653651

[58] Saremi, H. and Mohammadi, S. (2015) The Relationship between Transparency and Accountability in Public Accounting. Research Journal of Finance and Accounting, 6, 189-191.

[59] Birkinshaw, P. (2006) Transparency as a Human Right. In: British Academy: Proceedings, Oxford University Press, Oxford, 47-58. 
https://doi.org/10.5871/bacad/9780197263839.003.0003

[60] Fox, J. (2007) The Uncertain Relationship between Transparency and Accountability. Development in Practice, 17, 663-671. https://doi.org/10.1080/09614520701469955

[61] Meijer, A. (2014) Transparency. In: Bovens, M., Goodin, R.E. and Schillemans, T., Eds., The Oxford Handbook of Public Accountability, Oxford University Press, Oxford, 507-524.

[62] Boos, D., Guenter, H., Grote, G. and Kinder, K. (2012) Controllable Accountabilities: The Internet of Things and Its Challenges for Organizations. Behavior and Information Technology, 32, 449-467. https://doi.org/10.1080/0144929X.2012.674157

[63] Ministry of Education (2009) School Sector Reform Plan 2009-2015. Author, Kathmandu.

[64] Hwang, K. (2018) Bureaucratic Accountability and Performance. In: Farazmand, A., Ed., Global Encyclopedia of Public Administration, Public Policy, and Governance, Springer, Cham, 1-5. https://doi.org/10.1007/978-3-319-31816-5_3321-1

[65] Lawson, A. and Rakner, L. (2005) Understanding Patterns of Accountability in Tanzania. Final Synthesis Report Commissioned by the Governance Working Group of the Development Partners to Tanzania. Chr. Michelsen Institute, Bergen.

[66] Demirel, D. (2014) Accountability and the Changing Function of the Control/Hesap Verebilirlik ve Denetimin Degisen Islevi. Çanakkale Onsekiz Mart Üniversitesi Yönetim Bilimleri Dergisi, 12, 75-86.

[67] Grote, G. (2009) Management of Uncertainty: Theory and Application in the Design of Systems and Organizations. Springer, London.

https://doi.org/10.1007/978-1-84882-373-0

[68] Merchant, K.A. and Otley, D.T. (2006) A Review of the Literature on Control and Accountability. In: Chapman, C., Hopwood, A.G. and Shields, M.D., Eds., Handbooks of Management Accounting Research, Vol. 2, Elsevier Science, Amsterdam, 785-802. https://doi.org/10.1016/S1751-3243(06)02013-X

[69] Weber, M. (1968) Economy and Society. Bedminster, New York.

[70] Boos, D. and Grote, G. (2012) Designing Controllable Accountabilities of Future Internet of Things Applications. Scandinavian Journal of Information Systems, 24, 3-28. 